\title{
Chemical Composition, Toxicological, Ethno-Medicinal and Pharmacological Reports of Annona senegalensis: A Review
}

\author{
Babalola SB', Adebiyi YH², Lawal A ${ }^{3}$, Ajiboye J ${ }^{4}$, \\ and Berinyuy $\mathbf{E B}^{5 *}$ \\ ${ }^{1}$ Department of Chemistry, Federal University of \\ Technology Minna, Nigeria \\ ${ }^{2}$ Department of Biochemistry, Federal University of \\ Technology Minna, Nigeria \\ ${ }^{3}$ Department of Chemistry, University of Ilorin, Nigeria \\ ${ }^{4}$ Department of Animal Biology, Federal University of \\ Technology Minna, Nigeria \\ ${ }^{5}$ Faculty of Medicine and Biomedical Sciences, University \\ of Yaoundé 1, Yaoundé, Cameroon \\ *Corresponding author: Eustace B. Berinyuy, Faculty \\ of Medicine and Biomedical Sciences, University of \\ Yaoundé 1, Yaoundé, Cameroon
}

Received: February 20, 2021; Accepted: March 13, 2021; Published: March 20, 2021

\begin{abstract}
Annona senegalensis is a traditional medicinal plant commonly used in traditional medicine for the treatment of various diseases. It belongs to a family of Annonaceae and commonly known by the name of Wild Custard Apple and Wild Soursop, etc. It is a shrub or small tree 2-6 $\mathrm{m}$ tall but may reach $11 \mathrm{~m}$ under favorable conditions. It is widely spread throughout tropics and sub-tropics. It is commonly used for therapeutic fighting of major diseases including dysentery, diabetes mellitus, heart stroke, epilepsy, parasite and worm infestations, constipation, hemorrhage, dysuria, fever, ulcer, and cancers. The plant has also been reported for several biological activities including anti-oxidant, antidiarrheal, antimicrobial, antiparasitic, anticonvulsant, antitrypanosomal, antimalarial, anti-inflammatory, anti-snake venom, and antinociceptive properties. In order to provide sufficient baseline information for future works and commercial exploitation, this review represents the ethnomedicinal properties, phytochemicals composition, pharmacological properties, and safety/toxicity profile of $A$. senegalensis.
\end{abstract}

Keywords: Annona senegalensis; Chemical composition; Toxicological; Ethno-medicinal; Pharmacological

\section{Introduction}

From ancient time to recent days, natural products particularly medicinal plants have a medicinal reputation in the management and treatments of several diseases, including cancers, diabetics, metabolic disorders, degenerative disease, parasitic and infectious disease, inflammatory diseases, and oxidative stress-induced diseases [1-4]. In addition, increase scientific research has been focused on identifying and isolating bioactive agents in medicinal plants [5]. Furthermore, natural products are bio-friendly and have demonstrated higher safety properties compared to conventional therapies which are besieged with adverse effects [6-9].

Annona senegalensis, is a small tree that belongs to the Annonaceae family commonly known as Wild Custard Apple and Wild Soursop, it is also known as Gwándàn dààì̀ in Hausa or dukuu-hi in Fulani speaking part of Nigeria. It is native to tropical east and northeast, west and west-central, and southern Africa, as well as southern subtropical Africa, and islands in the western Indian Ocean. In Nigeria, it is widely distributed in Northern part, primarily in Kaduna, Nasarawa, Kano, Plateau, and Niger States and in the Federal Capital Territory, Abuja [10]. It is a shrub or small tree 2-6 $\mathrm{m}$ tall but may reach $11 \mathrm{~m}$ under favourable conditions. The bark is often roughish and grey-brown while the leaves are simple alternate, oblong, ovate or elliptic, green to bluish-green, mostly lacks hairs on upper surface, with brownish hairs on the lower surface. The flowers are up to $3 \mathrm{~cm}$ in diameter while the fruits are formed from many fused carpels [11].

Annona senegalensis is commonly us for therapeutic fighting of major diseases including dysentery, diabetes mellitus, heart stroke, epilepsy, parasite and worm infestations, constipation, hemorrhage, dysuria, fever, ulcer, and cancer [12]. The plant has also been reported for several biological activities including anti-oxidant, antidiarrheal, antimicrobial, antiparasitic, anticonvulsant, antitrypanosomal, antimalarial, anti-inflammatory, anti-snake venom and antinociceptive properties $[10,12]$. In the present study, we provided a review of traditional uses, Phyto-constituents, scientifically validated biological activities and safety/toxicity profile of Annona senegalensis.

\section{Nutritional and Phyto-Compositions of Annona senegalensis Pers}

Annona senegalensis has been reported to contain $12.20 \%$ moisture, $12.10 \%$ ash, $24.00 \%$ fat, $17.60 \%$ crude fibre, $8.80 \%$ crude protein and $25.3 \%$ of carbohydrate, respectively [13]. The mineral composition of $A$. senegalensis include potassium, phosphorus, calcium, sodium, magnesium, sulphur, chlorine, aluminum, silicon, vanadium, chromium, manganese, iron, nickel, copper, zinc, selenium, brome, molybdenum, tin, iodine, barium, and lead [14]. The phytochemical screening indicates the presence of saponins, steroid, flavonoid and glycoside in the sample. GC-MS analyses of essential oil of Annona senegalensis stem bark revealed the presence of p-cymene (36.0\%), a-phellandrene (25.0\%), a-pinene $(8.3 \%)$, Z-sabinol (6.9\%) and limonene (4.8\%) [15]. While the essential oil from the leaves had oxygenated monoterpenes $(65.0 \%)$, citronellal (30.0\%), citronellol (14.8\%), geranial (17.2\%), thymol (8.1\%), $\beta$ caryophyllene (7.8\%) and carvacrol (6.92\%) [16]. The plant has high values of amino acid content comparable to Food and Agricultural Organization/World Health Organization (FAO/WHO) standard.
J Drug Discov Develop and Deliv - Volume 7 Issue 1 - 2021 ISSN : 2471-0288 | www.austinpublishing group.com Berinyuy et al. (@) All rights are reserved
Citation: Babalola SB, Adebiyi YH, Lawal A, Ajiboye J and Berinyuy EB. Chemical Composition, Toxicological, Ethno-Medicinal and Pharmacological Reports of Annona senegalensis: A Review. J Drug Discov Develop and Deliv. 2021; 7(1): 1038. 
In addition, fermentation of Annona senegalensis have been reported to enhance the nutritional contents and decreased the anti-nutrient contents of the seeds. Thus, large-scale production of fermented $A$. senegalensis seeds will be a valuable source of nutrients for humans and anima [17].

\section{Ethno-Medicinal Uses of Annona senegalensis Pers}

Annona senegalensis Pers. (Annonaceae) is a multipurpose plant with a high medicinal reputation in traditional medical practice. $A$. senegalensis has been used in traditional medical practice for the management of various diseases. The plant is commonly used as a stimulant, pain reliever, anti-oxidant, antidiarrheal, antimicrobial, antiparasitic, anticonvulsant, antitrypanosomal, antimalarial, antiinflammatory, anti-snake venom, and antinociceptive properties and many other biomedical properties of pharmaceutical relevance $[10,12]$. The leaves have been reportedly used for the treatments of tuberculosis, yellow fever, smallpox $[18,19]$. The stem bark has been used for treatments of injury from venomous animals and in treatments of hernias [20]. The root is effective in treating gastritis, reproductive deficiency, snake bites, impotence, erectile dysfunction, tuberculosis, and infectious diseases [21], and in the management of diabetes and malaria [22].

\section{Biological Activity of Annona senegalensis Pers}

Antimicrobial activity: Crude ethanol, methanol-methylene chloride extract, and fractions of $A$. senegalensis has been reported for antimicrobial activities against both gram negative and grampositive bacteria including Bacillus subtilis, Staphylococcus aureus, Pseudomonas aeruginosa, and fungi with MIC range between 30-150 $\mu \mathrm{g} / \mathrm{ml}$ while it inhibits fungi Candida albicans and Aspergillus niger with MIC range between 30-250 $\mu \mathrm{g} / \mathrm{ml}$ [23-25]. Ethanol extract of $A$. senegalensis has also been reported for antimicrobial activity against some oral pathogens [26].

Antiplasmodial activity: Annona senegalensis has been reported for antiplasmodial activity against Plasmodium species exhibiting $57.1 \%$ and $91.1 \%$ suppression of parasite at extract concentrations of 100 and $800 \mathrm{mg} / \mathrm{kg} \mathrm{BW} \mathrm{[27].} \mathrm{Furthermore,} \mathrm{Ajaiyeoba} \mathrm{et} \mathrm{al.} \mathrm{[28]}$ reported that, the methanol extract of Annona senegalensis exhibited higher anti- Plasmodium berghei activity than the standard drug, chloroquine disphosphate.

Cytotoxic activity: Annona senegalensis exhibited a cytotoxic effect against A2780 ovarian cancer cells with an $\mathrm{IC}_{50}$ of $28.8 \mu \mathrm{g} /$ $\mathrm{ml}$ [29]. In addition, different fractions of the A. senegalensis have shown mild to moderate cytotoxicity effect in brine shrimp lethality bioassays [30,31]. Aporphine alkaloid from A. senegalensis has been reported for the cytotoxic effect [32].

Antioxidant activity: Annona senegalensis have been reported to exhibit ameliorative effect on $\mathrm{CCl}_{4}$-induced hepatocellular damage in rats [33].

Antitrypanosomal activity: Various extract and fractions of Annona senegalensis have been reported for significant in vivo antitrypanosoma effects, with little or no in vitro effects [34-37], with acetogenins been the active compound identified in the seeds extract [38].
Anti-Inflammatory and analgesic activities: A. senegalensis stem back methanol extract have been reported for significant dose-dependent anti-inflammatory activities in hot plate test and egg albumin induced paw oedema [39]. The authors reported a comparable anti-inflammatory activity to standard drugs pentazocine and piroxicam. The ethanol leaf extract of the plant also demonstrated significant anti-inflammatory effects [40]. Adzu et al. [41] also reported the anti-nociceptive effects of the methanolic root bark extract of Annona senegalensis. The chloroform root extract of Annona senegalensis $\mathrm{L}$ have also been reported for analgesic activity [42].

Anthelmintic activity: Ethanol leaf extract of A. senegalensis at $.8 \% \mathrm{w} / \mathrm{v}$ have been reported to induce $98.33 \%$ lethality of Haemonchus contortus larvae [43]. In addition, inhibition of egg hatching at $7.1 \mathrm{mg} /$ $\mathrm{ml}$ of the whole plant was achieved [44]. The identified anthelminthic compound in the A. senegalensis root extract included glaucanisine, glaucanetine, goniothalamicine, liriodenine, gigantetronenine, squamocine and norolivéroline [45].

Hypnotic activity: Crude extract and fractions of A. senegalensis leaves have been reported to dose-dependently and significantly $(p<0.05)$ decreases the sleep latency and prolonged sleeping time in pentobarbitone-induced sleeping animal model [46]. Furthermore, in an phenobarbitone assays, the root bark extract of A. senegalensis potentiated the central nervous system depressant effect of phenobarbitone in a dose dependent manner [47].

Other activities: Kitadi et al. [14] reported the anti-sickling effect of $A$. senegalensis, they demonstrated that aqueous extract of A. senegalensis significantly prevent the sickling and the hemolysis of red blood cells. Methanol root bark extract of Annona senegalensis has also been evaluated for anticonvulsant and muscle relaxant effects in mice, interestingly, the extract exhibited a non-dose dependent significant $(\mathrm{P}<0.05)$ delay in the onset of both tonic and clonic phases of seizure-induced by PTZ as well as offering $100 \%$ protection in mice from PTZ induced seizures at $200 \mathrm{mg} / \mathrm{kg}$ BW [48].

\section{Toxicity and Safety Properties of Annona senegalensis Pers}

Crude methanol-methylene chloride extract, methanol fraction, $\mathrm{n}$-hexane and ethyl acetate fraction of A. senegalensis had LD50 of 1 $296,3808,1265$ and $2154 \mathrm{mg} / \mathrm{kg}$ respectively in the acute oral toxicity study [49], while the methanol root bark extract of Annona senegalensis have oral LD50 of $1,296 \mathrm{mg} / \mathrm{kg}$ [48]. Subacute administration of the extracts at 100 and $400 \mathrm{mg} / \mathrm{kg}$ doses produce no significant alterations $(p>0.05)$ to the activities of aspartate transaminases and alanine transaminase. Hematological and histopathological evaluations also indicated no significant alterations except for an increase in the total WBC count and hepatocytes degeneration observed at the highest dose. Furthermore, the extract enhances the weight gain of the animals [49]. Coherently, another study revealed that a 28 days' administration of aqueous extract of $A$. senegalensis did not significantly alter $(\mathrm{p}>0.05)$ the blood serum biochemical parameters such as total proteins, alanine Aminotransferase (ALT), glucose, creatinine, and lipid levels of the treated mice [50]. However, Adisa et al. [51] reported that Annona senegalensis is relatively safe, but prolonged ingestion could induce oxidative stress and impair ATP synthesis through the modulation of the activity of mitochondrial 
succinate dehydrogenase.

\section{Conclusion}

The present review summarizes information concerning the ethnomedicinal properties, phytochemicals composition, pharmacological properties and safety/toxicity profile and toxicological reports of A. senegalensis. This review aims at gathering the research work undertaken till date on this plant in order to provide sufficient baseline information for future works and commercial exploitation.

\section{References}

1. Adesina DA, Adefolalu SF, Jigam AA, Lawal B. Antiplasmodial effect and sub-acute toxicity of alkaloid, flavonoid and phenolic extracts of Sida acuta leaf on Plasmodium berghei-infected animals. Journal of Taibah University for Science. 2020; 14: 943-953.

2. Ibrahim J, Kabiru AY, Abdulrasheed-Adeleke T, Lawal B, Adewuyi AH. Antioxidant and hepatoprotective potentials of curcuminoid isolates from turmeric (Curcuma longa) rhizome on $\mathrm{CCl}_{4}$-induced hepatic damage in Wistar rats. Journal of Taibah University for Science. 2020; 14: 908-915.

3. Lawal B, Shittu OK, Kabiru AY, Jigam AA, Umar MB, Berinyuy EB, et al Potential antimalarials from African natural products: A reviw. J Intercult Ethnopharmacol. 2015; 4: 318-343.

4. Lawal B, Shittu OK, Oibiokpa FI, Berinyuy EB. Mohammed, H. African natural products with potential antioxidants and hepatoprotectives properties: a review. Clinical Phytoscience. 2016; 2: 23.

5. Kim JH, Kismali G, Gupta SC. Natural Products for the Prevention and Treatment of Chronic Inflammatory Diseases: Integrating Traditional Medicine into Modern Chronic Diseases Care. Evidence-Based Complementary and Alternative Medicine. 2018; 2018: 9837863.

6. Yusuf AA, Lawal B, Yusuf MA, Adejoke AO, Raji FH, Wenawo DL. Free radical scavenging, antimicrobial activities and effect of sub-acute exposure to Nigerian Xylopia Aethiopica seed extract on liver and kidney functional indices of albino rat. Iranian journal of toxicology. 2018; 12: 51-58.

7. Umar SI, Lawal B, Mohammed BA, Obiekezie Cl, Adewuyi AH, Babalola SB, et al. Antioxidant and antimicrobial activities of naturally occurring flavonoids from $M$. heterophylla and the safety evaluation in Wistar rats. Iranian Journal of Toxicology. 2019; 13: 39-44.

8. Shittu OK, Lawal B, Alozieuwa BU, Haruna GM, Abubakar AN, Berinyuy EB. Alteration in biochemical indices following chronic administration of methanolic extract of Nigeria bee propolis in Wistar rats. Asian Pacific Journal of Tropical Disease. 2015; 5: 654-657.

9. Lawal B, Shittu OK, Oibiokpa FI, Mohammed H, Umar SI, Haruna GM Antimicrobial evaluation, acute and sub-acute toxicity studies of Allium sativum. Journal of Acute Disease. 2016; 5: 296-301.

10. Okhale SE, Akpan E, Fatokun OT, Esievo KB, Kunle OF. Annona senegalensis Persoon (Annonaceae): a review of its ethnomedicinal uses, biological activities and phytocompounds. Journal of Pharmacognosy and Phytochemistry. 2016; 5: 211.

11. Orwa C. Agroforestree Database: a tree reference and selection guide, version 4.0. 2009.

12. Djoza RD, Ashande CM, Mpiana PT. A mini-review on the pharmacognosy and phytochemistry of a tropical medicinal plant: Annona senegalensis Pers. (Annonaceae). Tropical Plant Research. 2017; 4: 168-175.

13. Yisa J, Egila J, Darlinton A. Chemical composition of Annona senegalensis from Nupe land, Nigeria. African Journal of Biotechnology. 2010; 9: 41064109.

14. Kitadi JM, Inkoto CL, Lengbiye EM, Tshibangu, DS, Tshilanda DD, Taba $\mathrm{K}$, et al. Mineral content and antisickling activity of Annona senegalensis, Alchornea cordifolia and Vigna unguiculata used in the management of sickle cell disease in the Kwilu province (CONGO, DR). International Blood Research \& Reviews. 2020: 18-27.
15. Khallouki F, Younos C, Soulimani R, Bessière JM. Chemical composition of the essential oils of Annona cuneata L. and Annona senegalensis Pers. stem barks. Flavour and fragrance journal. 2002; 17; 398-400.

16. Ameen O, Usman L, Oganija F, Hamid A, Muhammed N, Zubair M, et al. Chemical composition of leaf essential oil of Annona senegalensis Pers. (Annonaceae) growing in North Central Nigeria. International Journal of Biological and Chemical Sciences. 2011: 5.

17. Mathew J, Dauda B, Mann A, Ndamitso M, Etsuyankpa M, Shaba E. Assessment of the nutritive and anti-nutritive compositions of fermented and unfermented African custard apple (Annona senegalensis) seeds from Niger state, Nigeria. FUW Trends in Science \& Technology Journal. 2018; 3: 471477.

18. Aiyeloja A, Bello O. Ethnobotanical potentials of common herbs in Nigeria: A case study of Enugu state. Educational Research and Reviews. 2006; 1: 16-22.

19. Mustapha AA, Owuna G, Uthman IHI. Plant remedies practiced by Keffi people in the management of dermatosis. Journal of Medicinal Plants. 2013; 1: $112-118$.

20. Dambatta SH, Aliyu B. A survey of major ethno medicinal plants of Kano north, Nigeria, their knowledge and uses by traditional healers. Bayero Journal of Pure and Applied Sciences. 2011; 4: 28-34.

21. Emmanuel N, Mamoudou S. Some Investigations on the Traditional Pharmacopoeia about Venomous Bites and Stings from Scorpions, Snakes and Spiders; in the Hina Subdivision, Far-North, Cameroon. Journal of Pharmaceutical Research International. 2015: 344-358.

22. Igoli J, Ogaji O, Tor-Ayiin T, Igoli N. Traditional medicine practice amongst the Igede people of Nigeria. Part II. African Journal of Traditional, Complementary and Alternative Medicines. 2005; 2: 134-152.

23. Jada MS, Usman WA, Olabisi AO. Crude flavonoids isolated from the stem bark of Annona senegalensis have antimicrobial activity. Journal of Advances in Biology \& Biotechnology. 2015: 24-29.

24. Ijaiya IS, Arzika S, Abdulkadir M. Extraction and Phytochemical Screening of the Root and Leave of Annona Senegalensis (Wild Custad Apple). Academic Journal of Interdisciplinary Studies. 2014; 3 : 9.

25. Aiyeloja AA, Bello OA. Ethnobotanical Potentials of Common Herbs in Nigeria: A Case Study of Enugu State. Educational Research Review. 2006; 1: $16-22$.

26. More G, Tshikalange TE, Lall N, Botha F, Meyer JJ. Antimicrobial activity of medicinal plants against oral microorganisms. Journal of ethnopharmacology. 2008; 119: 473-477.

27. Ajaiyeoba E, Falade M, Ogbole O, Okpako L, Akinboye DO. In Vivo Antimalarial and Cytotoxic Properties of Annona Senegalensis Extract African Journal of Traditional, Complementary and Alternative Medicines. 2005; 3: 137-141.

28. Ajaiyeoba E, Falade M, Ogbole O, Okpako L, Akinboye D. In vivo antimalarial and cytotoxic properties of Annona senegalensis extract. African Journal of Traditional, Complementary and Alternative Medicines. 2006; 3: 137-141.

29. Ahmed A, Bassem SM, Mohamed Y, Gamila M. Cytotoxic essential oil from Annona senegalensis Pers. leaves. Pharmacognosy Research. 2010; 2: 211214.

30. Magadula J, Innocent E, Otieno J. Mosquito larvicidal and cytotoxic activities of 3 Annona species and isolation of active principles. Journal of Medicinal Plants Research. 2009; 3: 674-680.

31. Ajaiyeoba E, Abiodun O, Falade M, Ogbole NO, Ashidi JS, Happi C, et al. In vitro cytotoxicity studies of 20 plants used in Nigerian antimalarial ethnomedicine. Phytomedicine: international journal of phytotherapy and phytopharmacology. 2006; 13: 295-298.

32. Ngbolua K, Mudogo V, Mpiana P, Tshibangu D, Tshilanda D, Masengo C In vitro and in vivo anti-malarial and cytotoxic activities of ethanolic extracts of Annona senegalensis Pers (Annonaceae) from Democratic Republic of the Congo. Journal of Modern Drug Discovery and Drug Delivery Research. $2014 ; 2: 1-5$. 
33. Ajboye TO, Yakubu M, Salau AK, Oladiji AT, Akanji MA, Okogun J. Antioxidant and drug detoxification potential of aqueous extract of Annona senegalensis leaves in carbon tetrachloride-induced hepatocellular damage. Pharmaceutical Biology. 2010; 48: 1361-1370.

34. Ogbadoyi EO, Abdulganiy AO, Adama T, Okogun J. In vivo trypanocida activity of Annona senegalensis Pers. leaf extract against Trypanosoma brucei brucei. Journal of ethnopharmacology. 2007; 112: 85-89.

35. Youan B, Coulibaly S, Miezan TB, Doua F, Bamba M. In vivo evaluation of sixteen plant extracts on mice inoculated with Trypanosoma bruce gambiense. Bulletin of the World Health Organization. 1997; 75: 343-348.

36. Atawodi S. Comparative in vitro trypanocidal activities of petroleum ether chloroform, methanol and aqueous extracts of some Nigerian savannah plants. African Journal of Biotechnology. 2005: 4.

37. Kabiru A, Salako AA, Ogbadoyi EO. Therapeutic Effects of Annona senegalensis Pers Stem Bark Extracts in Experimental African Trypanosomiasis. International Journal of Health Research. 2011; 3: 45-49.

38. Ahpaz S, Bories C, Loiseau P, Cortés D, Hocquemiller R, Laurens A, et al. Cytotoxic and antiparasitic activity from Annona senegalensis seeds. Planta medica. 1994; 60: 538-540.

39. Suleiman M, Mamman M, Igomu EE, Muhammad Y, As A, Talba AM Evaluation of analgesic and anti-inflammatory effects of the crude methanol extract of the stem-bark of Annona senegalensis Pers. International Journal of Medicinal and Aromatic Plants. 2014; 4: 88-96.

40. Yéo D, Dinic R, Yapi HF, Furdui B, Praisler M, Djaman AJ, et al. [Evaluation of the anti-inflammatory activity and phytochemical screening of Annona senegalensis leaves]. Therapie. 2011; 66: 73-80.

41. Adzu B, Amos S, Adamu M, Gamaniel K. Anti-nociceptive and Antiinflammatory Effects of the Methanol Extract of Annona senegalensis Root Bark. Journal of Natural Remedies. 2003; 3: 63-67.

42. Odoh U, Ezugwu C, Ajali U. Preliminary investigation of the analgesic activity of the chloroform root extract of Annona senegalensis L. J Pharm Allied Sci. $2004 ; 2 ; 169-172$.
43. Monglo D, LM Njongmeta, G Musongong, M Ngassoum, Nukenine EN Evaluation of Anthelmintic Potential of Ethanolic Plant Extracts from Northern Cameroon against Eggs and Infective Larvae of Haemonchus contortus. Journal of Biological Sciences. 2006; 6: 426-433.

44. Alawa C, Adamu AM, Gefu J, Ajanusi OJ, Abdu P, Chiezey N, et al. In vitro screening of two Nigerian medicinal plants (Vernonia amygdalina and Annona senegalensis) for anthelmintic activity. Veterinary parasitology. 2003; 113: 73-81.

45. Fall D, Sambou B, Seck M, Wele A, Ndoye I, Gleye C, et al. [Enhancing the anthelminthic activity roots of Annona senegalensis]. Dakar medical. 2008; 53: 61-67.

46. Okoli CO, Onyeto C, Akpa B, Ezike AC, Akah P, Okoye TC Neuropharmacological evaluation of Annona senegalensis leaves. African Journal of Biotechnology. 2010; 9: 8435-8444.

47. Otimenyin S, Omeri F. Hypnotic effect of methanolic extracts of Annona senegalensis bark and ficus thonningii leaves in mice and chicks. IJPPR. HUMAN. 2014; 1: 1-12.

48. Okoye T, Akah P, Omeke C. Evaluation of the anticonvulsant and muscle relaxant effects of the methanol root bark extracts of Annona senegalensis. Asian Pacific Journal of Tropical Medicine. 2010; 3: 25-28.

49. Okoye TC, Akah PA, Ezike AC, Okoye MO, Onyeto CA, Ndukwu F, et al. Evaluation of the acute and sub-acute toxicity of Annona senegalensis root bark extracts. Asian Pacific Journal of Tropical Medicine. 2012; 5: 277-282.

50. Ilboudo S, Ouedraogo GG, Ouedraogo S, Guissou IP. Phytochemical, acute and subacute toxicity studies of Annona senegalensis Pers. (Annonaceae) root wood extracts. African Journal of Biochemistry Research. 2019; 13: 4455.

51. Adisa RA, Kolawole N, Sulaimon LA, Brai B, ljaola A. Alterations of Antioxidant Status and Mitochondrial Succinate Dehydrogenase Activity in the Liver of Wistar Strain Albino Rats Treated with by Ethanol Extracts of Annona senegalensis Pers (Annonaceae) Stem Bark. Toxicol Res. 2019; 35: 13-24. 